\title{
Hispano-Moresque ceramic tiles from the Monastery of Santa Clara-a-Velha (Coimbra, Portugal)
}

\author{
Susana Coentro ${ }^{\mathrm{a}, \mathrm{b}}$, Rui A.A. Trindade ${ }^{\mathrm{c}}$, José Mirão ${ }^{\mathrm{d}}$, António Candeias ${ }^{\mathrm{d}}$, Luís C. Alves ${ }^{\mathrm{b}, \mathrm{e}}$, \\ Rui M.C. Silva ${ }^{\mathrm{b}, \mathrm{e}}$, Vânia S.F. Muralha ${ }^{\mathrm{a}, *}$ \\ a VICARTE - Research Unit "Glass and Ceramics for the Arts", Faculdade de Ciências e Tecnologia da Universidade Nova de Lisboa, \\ 2829-516 Caparica, Portugal \\ ${ }^{\mathrm{b}}$ IST/ITN, Instituto Superior Técnico, Universidade Técnica de Lisboa, Estrada Nacional 10, 2695-066 Bobadela, Portugal \\ ${ }^{c}$ Instituto de História da Arte, Faculdade de Ciências Sociais e Humanas da Universidade Nova de Lisboa, Av. de Berna 26-C, 1069-061 Lisboa, Portugal \\ ${ }^{\mathrm{d}}$ Laboratório HÉRCULES, Largo Marquês de Marialva 8, 7000-554 Évora, Portugal \\ ${ }^{\text {e } C F N U L, ~ A v . ~ P r o f . ~ G a m a ~ P i n t o ~ 2, ~ 1649-003 ~ L i s b o a, ~ P o r t u g a l ~}$
}

\section{A R T I C L E I N F O}

\section{Article history:}

Received 9 April 2013

Received in revised form

22 July 2013

Accepted 26 July 2013

Keywords:

Artist tiles

Hispano-Moresque

Glaze-ceramic interface

\begin{abstract}
A B S T R A C T
A group of late 15th-early 16th century Hispano-Moresque glazed tiles from the Monastery of Santa Clara-a-Velha, in Coimbra, were, for the first time, characterised chemically and morphologically. Since the prevailing idea among art historians in Portugal is to judge the Hispano-Moresque tile heritage as Spanish production, the findings concerning technological processes were compared with the Islamic technology in the Iberian Peninsula and latter Hispano-Moresque in Spain. This study is the first analytical indicator of a production technology with some differences from the Hispano-Moresque workshops (such as Seville, Toledo, etc.) and points out to a possible local production. Five different coloured glazes were identified: white, blue, green, amber and black, all displaying high-lead content, as expected for this type of ceramics. Tin oxide was identified in high contents (7-14 wt.\%) in white and blue glazes, its crystals homogenously distributed in also very homogeneous glazes, showing similarities with an Islamic glazing technology. On the other hand, Ca-rich thick glaze-ceramic interfaces were observed, with many mineral inclusions (wollastonite $\left(\mathrm{CaSiO}_{3}\right)$ and also K-feldspars (general formula $\mathrm{KAlSi}_{3} \mathrm{O}_{8}$ ), showing a higher resemblance with a later Hispano-Moresque technology. Other compounds were also identified from reactions involving the colour compound: malayaite $\left(\mathrm{CaSnOSiO}_{4}\right)$, bustamite $\left(\mathrm{CaMnSi}_{2} \mathrm{O}_{6}\right)$, braunite $\left(\left(\mathrm{Mn}^{2+}, \mathrm{Mn}^{3+}\right)_{6} \mathrm{O}_{8} \mathrm{SiO}_{4}\right)$, andradite $\left(\mathrm{Ca}_{3} \mathrm{Fe}_{2} \mathrm{Si}_{3} \mathrm{O}_{12}\right)$, magnesioferrite $\left(\mathrm{MgFe}_{2} \mathrm{O}_{4}\right)$ and a nickel ferrite $\left(\mathrm{NiFe}_{2} \mathrm{O}_{4}\right)$. The chemical composition of this glaze-ceramic interface suggests firing temperatures between $950{ }^{\circ} \mathrm{C}$ and $1000{ }^{\circ} \mathrm{C}$ and its thickness implies a single-fire process. The chemical characterisation does not suggest different recipes or different firing processes for cuerda seca and arista tiles.
\end{abstract}

(c) 2013 Elsevier Ltd. All rights reserved.

\section{Introduction}

Hispano-Moresque glazed tiles were profusely used throughout the Portuguese territory in the 15th and 16th centuries. This very specific artistic ceramic object represents the beginning of a decorative art that has been characteristic of Portuguese public art ever since, azulejos. The designation "Hispano-Moresque" arises

\footnotetext{
* Corresponding author. Tel.: +351 212948322.

E-mail addresses: scoentro@campus.fct.unl.pt (S. Coentro), ruieatrindade@ gmail.com (R.A.A. Trindade), jmirao@uevora.pt (J. Mirão), candeias@uevora.pt (A. Candeias), lcalves@ctn.ist.utl.pt (L.C. Alves),rmcs@ctn.ist.utl.pt (R.M.C. Silva), solange@fct.unl.pt (V.S.F. Muralha).
}

from a technological proximity to Islamic glazed ceramics and developed through the simplification of the glaze technique of decoration, from the alicatado (small monochromatic tiles cut into geometric forms) to cuerda seca and then to the arista technique. On the other hand, the geometric Islamic decorations evolved to more complex figurative Renaissance motifs (Martínez Caviró, 1996). Hispano-Moresque production of glazed ceramics used and developed the technology that was brought to the Iberian Peninsula by the Islamic conquerors in the late 8th century (Molera et al., 1997a).

The supported thesis in Portuguese art history attributes all examples of Hispano-Moresque tiles in Portugal as imports from the Spanish territory, namely Seville, Toledo and Valencia. Nevertheless this attribution has recently been questioned due to several 
archaeological findings of production evidences and a review of the existing records on ceramic coatings in the Portuguese territory, including Coimbra (Trindade, 2007). The present paper is included in a wider study aiming to unveil the technology of manufacture of several important medieval collections of Hispano-Moresque tiles in Portugal and ultimately, determining their provenance.

An extraordinary tile collection was excavated at the Monastery of Santa Clara-a-Velha, located in central Portugal (Coimbra), today a beautiful historical ruin of a medieval church and cloister that was submersed for centuries. Located near the shores of the river Mondego, the monastery was often flooded, which ultimately led to the construction of a new Santa Clara Monastery (Monastery of Santa Clara-a-Nova) at a higher adjacent location. Founded in 1283, and (to be) dedicated to the ways of the Order of Saint Clare or Clarisses, the Monastery of Santa Clara-a-Velha was definitely abandoned in 1677 (Côrte-Real et al., 2010). During the last decades of the 20th century, several archaeological campaigns uncovered a vast collection of Hispano-Moresque architectural tiles dated from the 15th to the first half of the 16th century (Côrte-Real et al., 2010), with examples of cuerda seca and arista tiles on the floor and walls, flat monochromatic tiles on a fountain located in the cloister, relief tiles with star-shaped motifs on the ceiling of the church, and also blue-and-white rajolas (pre-majolica) on the raiser of the steps in the cloister. Some tiles show anthropomorphic examples, which have not been identified elsewhere in the country.

Although the technological aspects of Hispano-Moresque ceramics have been the subject of a number of important studies (Molera et al., 1997a, 1997b, 2001b, 2009; Pérez-Arantegui et al., 1999, 2005; Vendrell-Saz et al., 2006), there is little information on coeval glazed tiles, while studies focussing on Portuguese collections are inexistent. With this study we wish to understand the technological procedures involved in the manufacture of this collection in correlation with the knowledge on Hispano-Moresque technology in Spain and also the Islamic technology in the Iberian Peninsula. To clarify this subject we try to summarize the main technological features known from studies on glazed ceramics in the Iberian Peninsula. Islamic and later Hispano-Moresque glazed ceramics were characterised by two types of glazes: transparent lead glazes and tin-opacified lead glazes. Studies on several ceramic workshops in the Spanish territory concluded that: (1) in Islamic workshops, a frit was used to produce the transparent glaze and applied on a previously fired ceramic support (double-firing process). Analytical results show very thin glaze-ceramic interfaces of pre-13th century glazes, indicating a double-firing process. Tinopacified glazes were also produced in this fashion, both in Islamic and in Hispano-Moresque workshops up to the 13th century (Molera et al., 2001b, 2009); (2) from the 13th century onwards frits were no longer in use and the ceramic objects were single-fired, a simplification preserved by Hispano-Moresque workshops (Vendrell-Saz et al., 2006). Molera et al. (2001b) suggest that 14th century tin glazes were no longer fritted, according to analytical results showing large and heterogeneously distributed tin oxide crystals. Another important observation that has to be taken into consideration is the distinct glaze-ceramic interface of single- and double-fired glazed ceramics, namely their morphology and the nature of the crystals found in this interface (Molera et al., 1997b, 2001a). A study on glaze-ceramic interactions by Molera et al. (2001a) revealed that a digestion process occurs between the lead glaze and the ceramic body during the firing, where compounds from the ceramic body diffuse into the glaze and vice-versa. The digestion/diffusion process occurs on smaller scale in previously fired ceramic bodies, originating thinner interfaces (ca. 5$10 \mu \mathrm{m}$ ) than for single-fired ceramics (ca. 30-40 $\mu \mathrm{m}$ ).

\section{Experimental procedure}

\subsection{Samples}

A set of 14 fragments of Hispano-Moresque glazed ceramic tiles provided by the Monastery of Santa Clara-a-Velha in Coimbra were analysed. Fig. 1 shows some samples where all the representative colours (white, blue, green, brown or black and amber) are depicted. The samples analysed comprised a representative set of the most common patterns and decoration techniques excavated in the Monastery of Santa Clara-a-Velha. Briefly, the glaze techniques of decoration found in Santa Clara-a-Velha are as follows: (1) the cuerda seca technique (image on the left), allowed the use of different coloured glazes on the same object, separated by grooves on the surface of the tile that were filled with a mixture of manganese oxide, most likely mixed with a flux, and a greasy substance; (2) the arista or cuenca (image on the middle), where the coloured glazes were separated by protruding contours obtained by pressing the ceramic paste onto a mould; (3) the relief technique (image on the right), where a mould is also used, but the pattern has a 3dimensional nature. Polished-cross sections of all samples were prepared by cutting a small piece of sample (ca. $0.5 \mathrm{~cm}$ ) with a diamond saw and mounting it in epoxy resin (Araldite $2020^{\circledR}$ ). Finally, samples were polished up to 4000 grit.

Although a large part of the collection was submersed for centuries, most tiles have their original glaze in a fairly good conservation state, except for the obvious weathering due to burial conditions that caused a loss of the original surface. It is surprising that glaze detachment is a minor conservation problem in this collection regarding the conditions in which it was preserved for so many centuries.
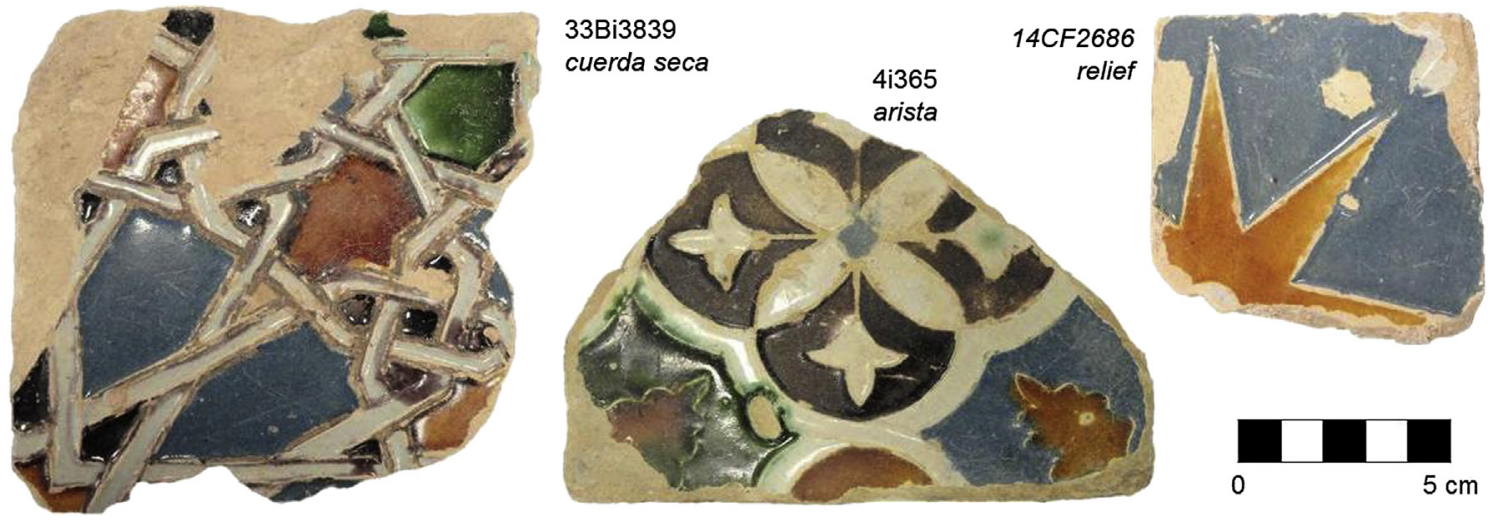

Fig. 1. Examples of studied samples and decoration techniques. 


\subsection{Analytical techniques}

$\mu$-PIXE: Micro Particle Induced X-Ray Emission ( $\mu$-PIXE) was performed using an Oxford Microbeams OM150 type scanning microprobe for focussing down to $3 \times 4 \mu \mathrm{m}^{2}$ a $1 \mathrm{MeV}$ proton beam. The sample fragments were irradiated in vacuum and the X-rays produced were collected by a $8 \mu \mathrm{m}$ thick Be windowed $\mathrm{Si}(\mathrm{Li})$ detector with a crystal active area of $80 \mathrm{~mm}^{2}$ and $145 \mathrm{eV}$ resolution. The system configuration used allows efficient detection of low energy X-rays such as the ones from Na. Operation and basic data manipulation, including elemental distribution mapping, was achieved through the OMDAQ software code, and quantitative analysis done with the DAN32 programme.

SEM-EDS: The equipment used for Scanning Electron Microscopy with Energy Dispersive Spectrometry (SEM-EDS) was a HITACHI S-3700N electron microscope with a Bruker Xflash 5010 SDD energy dispersive X-ray (EDX) detector. After carbon coating, all samples were observed and analysed under a vacuum atmosphere. The backscattering mode was used for SEM imaging. The resolution of the EDX detector is $123 \mathrm{eV}$ in the $\mathrm{Mn} \mathrm{K} \alpha$ line. The system allow reliable chemical point analysis and mapping from $\mathrm{Na}$ $\mathrm{X}$-ray emission energy. In order to collect X-ray emissions from heavier elements like $\mathrm{Pb}$, an acceleration voltage of $20 \mathrm{kV}$ was chosen. The EDX tasks and the quantification were achieved through the Esprit1.9 software from Bruker company.

Measurements of the glaze-ceramic interface were performed directly on the images during SEM-EDS analysis, using the SEM software. The thickness was considered to be the distance between the glaze and the ceramic body where an area of heterogeneous appearance, with a large number of mineral inclusions and small gas bubbles, is evident.

$\mu$-Raman: Analyses were performed with a Labram 300 Jobin Yvon spectrometer, equipped with a $\mathrm{He}-\mathrm{Ne}$ laser of $17 \mathrm{~mW}$ power operating at $632.8 \mathrm{~nm}$ and a solid state laser of $500 \mathrm{~mW}$ power operating at $532 \mathrm{~nm}$. The laser beam was focused either with a $50 \times$ or $100 \times$ Olympus objective lenses. The laser energy was filtered at $10 \%$ using a neutral density filter for all analyses. Analyses were performed both on the surface of the glazes and on polished crosssections. Spectra were recorded as an extended scan. A mixed Gaussian-Lorentzian curve-fit using the LabSpec software was used to determine the exact peak wavenumbers. The attribution of the Raman spectra was made using the RRUFF database project on minerals (RRUFF).

\section{Results and discussion}

\subsection{Chemical analysis of the glazes by $\mu$-PIXE and $\mu$-Raman}

Table 1 contains the results of the elemental $\mu$-PIXE analyses on the composition of the coloured glazes, expressed as mass fractions of the respective oxides relative to the total composition. As expected for lead glazes, $\mathrm{PbO}$ and $\mathrm{SiO}_{2}$ are the most important compounds in the glaze composition, making up for ca. 73-86 wt.\% of the total composition. Blue and white colours include $\mathrm{SnO}_{2}$ as the third most important compound, with contents of ca. 7-14 wt.\% (with one singular result of 19 wt.\%). It is followed by $\mathrm{CaO}(2-$ 5 wt.\%), $\mathrm{Al}_{2} \mathrm{O}_{3}$ (2-5 wt.\%), $\mathrm{K}_{2} \mathrm{O}$ (2-4 wt.\%) and $\mathrm{Na}_{2} \mathrm{O}$ (1-3 wt.\%). Chlorine is also present ( $<1 \mathrm{wt} . \%)$, which could indicate the use of ashes derived from coastal plants as fluxes or even the use of $\mathrm{NaCl}$ as a flux (Tite et al., 2006).

Some compounds such as $\mathrm{MgO}, \mathrm{Al}_{2} \mathrm{O}_{3}, \mathrm{CaO}, \mathrm{TiO}_{2}$ and $\mathrm{Fe}_{2} \mathrm{O}_{3}$ are present in all colours, probably related with the raw materials, e.g. sand used as a source of silica (Molera et al., 1997b) but they can also enter the glaze composition during firing through the aforementioned reaction with the ceramic body (Molera et al., 1997a, 1997b). The content of such compounds in the glaze can therefore be influenced by the production technique (e.g. number of firings, firing temperature).

From the $\mu$-PIXE analysis it is possible to differentiate two groups of colours that share a similar chemical composition in what concerns the $\mathrm{SnO}_{2}$ content, with white and blue in one group and amber (yellowish tone), green and black in the other, as shown in Fig. 2. Tin oxide $\left(\mathrm{SnO}_{2}\right)$ in the form of cassiterite crystals, is responsible for the white colour and opacity of the white and blue glazes. Blue and white glazes show $\mathrm{SnO}_{2}$ values of ca. 7-14 wt.\%, being described as opaque colours, and the other three colours present considerably lower results (ca. $0.5 \mathrm{wt} . \%$ to $1.8 \mathrm{wt} . \%$ ), being described as transparent colours. $\mathrm{SnO}_{2}$ was not detected in two glazes. The presence of $\mathrm{SnO}_{2}$ in yellow, green and black glazes was somewhat unexpected, since they are mostly transparent. However, small amounts of tin oxide have been identified in such glazes in 10th-12th century Islamic cuerda-seca ceramics from Spain and Portugal (Chapoulie et al., 2005).

Comparing our results with several Islamic and HispanoMoresque workshops in the Iberian Peninsula, tin oxide contents of white and blue glazes fall in the range of Islamic tin-glazed ceramics prior to the 13th century (Molera et al., 2001b; Chapoulie et al., 2005; Vendrell-Saz et al., 2006). Previous studies have shown that Islamic workshops used higher $\mathrm{SnO}_{2}$ contents, which decreased in Hispano-Moresque technology (Molera et al., 1997a; Vendrell-Saz et al., 2006). This resemblance to Islamic technology is also observed in other glaze characteristics that will be further discussed in Chapter 3.3.

Although this work is centred on the analysis of the glazes, SEMEDS quantitative analysis was performed on the ceramic body of a few samples showing a Ca-rich composition (with average compositions of ca. 40 wt\% $\mathrm{SiO}_{2}, 20 \mathrm{wt} \% \mathrm{CaO}$ and ca. $15 \mathrm{wt} \% \mathrm{Al}_{2} \mathrm{O}_{3}$ ), indicating a calcareous paste. Other oxides were identified in smaller amounts, such as $\mathrm{MgO}$ and $\mathrm{Fe}_{2} \mathrm{O}_{3}$ ( $<7 \mathrm{wt} \%$ ), as well as $\mathrm{Na}_{2} \mathrm{O}$ and $\mathrm{K}_{2} \mathrm{O}(<2 \mathrm{wt} \%)$. All samples show a buff-coloured clay body exhibiting either a stronger pink hue or a creamy one, which could be explained by small differences in the firing temperatures or firing atmosphere (Molera et al., 1998). When analysing the ceramic body by SEM-EDS we also found that, alongside the diffusion of Ca and other elements from the ceramic body to the glaze, the opposite has also occurred for lead. Lead diffusion from the glaze to the ceramic body has already been described by M. Vendrell-Saz et al. as an outcome of a reaction between the glaze and ceramic body during the firing process, and thus it is expected to extend further for single-fired ceramics (Vendrell-Saz et al., 2006).

\subsection{Colour composition of glazes}

Besides the white glaze, the other colours are obtained with transition metal oxides: cobalt oxide for blue, copper oxide for green, iron oxide for amber and manganese oxide for brown, all the component metallic elements identified by $\mu$-PIXE.

The blue pigment displays an element association of $\mathrm{Co}-\mathrm{Fe}-$ $\mathrm{Ni}-\mathrm{Cu}$, as determined by $\mu$-PIXE. This result is in agreement with recent studies showing a $\mathrm{Co}-\mathrm{Cu}-\mathrm{Ni}$ correlation in 14th to 16th century Spanish and Italian glazed ceramics (Roldán et al., 2006; Zucchiatti et al., 2006). The major source of cobalt in 16th century Europe was the mining district of Erzgebirge (Saxony), in Germany. Typically, a blue cobalt pigment imported from this region, subsequent to 1520 would include arsenic in its composition, while prior to this period the manufacture would lead to the loss of this element (Zucchiatti et al., 2006). The production of the tiles from Santa Clara-a-Velha fits this time period, and therefore, the region of Erzgebirge could be a possible source of cobalt. But other sources must be considered, as the mines of Teruel, in Spain, a well- 
Table 1

Chemical composition of the analysed tiles from the Monastery of Santa Clara-a-Velha, divided by technique and glaze colour, in wt.\% average.

\begin{tabular}{|c|c|c|c|c|c|c|c|c|c|c|c|c|c|c|c|c|c|c|}
\hline Sample & Technique & $\begin{array}{l}\text { Glaze } \\
\text { colour }\end{array}$ & $\mathrm{Na}_{2} \mathrm{O}$ & $\mathrm{MgO}$ & $\mathrm{Al}_{2} \mathrm{O}_{3}$ & $\mathrm{SiO}_{2}$ & $\mathrm{Cl}$ & $\mathrm{K}_{2} \mathrm{O}$ & $\mathrm{CaO}$ & $\mathrm{TiO}_{2}$ & $\mathrm{MnO}$ & $\mathrm{Fe}_{2} \mathrm{O}_{3}$ & $\mathrm{CoO}$ & $\mathrm{NiO}$ & $\mathrm{CuO}$ & $\mathrm{SnO}_{2}$ & $\mathrm{BaO}$ & $\mathrm{PbO}$ \\
\hline \multirow[t]{3}{*}{$4 \mathrm{i} 365$} & \multirow[t]{3}{*}{ Arista } & Blue & 2.78 & 0.80 & 2.35 & 42.0 & 0.47 & 3.10 & 3.39 & 0.16 & 0.02 & 1.97 & 0.39 & 0.15 & 0.11 & 9.96 & - & 32.4 \\
\hline & & Amber & 2.07 & 0.95 & 3.49 & 36.9 & 0.35 & 2.71 & 4.74 & 0.19 & - & 4.75 & - & - & 0.11 & 1.22 & - & 42.5 \\
\hline & & Brown & 1.06 & 1.20 & 3.26 & 33.8 & - & 2.68 & 5.30 & 0.19 & 2.92 & 3.51 & - & - & - & 1.07 & 0.29 & 44.8 \\
\hline \multirow[t]{3}{*}{10 ef175 } & \multirow[t]{3}{*}{ Arista } & White & 2.40 & 0.83 & 3.10 & 42.0 & 0.32 & 2.48 & 4.06 & 0.20 & 0.05 & 0.93 & - & - & 0.64 & 7.02 & - & 36.0 \\
\hline & & Blue & 2.40 & 0.64 & 2.47 & 40.1 & 0.58 & 2.87 & 2.78 & 0.16 & - & 2.36 & 0.51 & 0.22 & 0.38 & 8.52 & - & 36.0 \\
\hline & & Green & 1.62 & 0.87 & 3.09 & 39.7 & 0.36 & 2.12 & 4.15 & 0.20 & - & 1.01 & - & - & 2.06 & 1.46 & - & 43.3 \\
\hline \multirow[t]{4}{*}{ 10DF7637 } & \multirow{4}{*}{ Arista } & White & 1.82 & 1.20 & 2.54 & 41.6 & 0.23 & 1.86 & 3.18 & 0.19 & - & 0.92 & - & - & 0.25 & 13.68 & - & 32.5 \\
\hline & & Blue & 1.96 & 0.61 & 2.16 & 41.3 & 0.21 & 1.76 & 2.22 & 0.14 & - & 1.46 & 0.46 & 0.13 & 0.96 & 14.27 & - & 32.4 \\
\hline & & Amber & 1.27 & 0.76 & 3.76 & 35.2 & 0.32 & 1.98 & 3.96 & 0.28 & - & 4.51 & 0.07 & - & 0.35 & 0.42 & - & 47.2 \\
\hline & & Brown & 1.49 & 0.59 & 3.12 & 42.5 & - & 2.16 & 2.29 & 0.20 & 3.07 & 1.53 & - & - & 0.15 & - & 0.26 & 42.6 \\
\hline 14CF2686 & Relief & Blue & 2.01 & 0.78 & 2.19 & 39.4 & 0.23 & 1.97 & 2.65 & 0.15 & - & 1.51 & 0.30 & 0.21 & 0.45 & 12.56 & - & 35.6 \\
\hline \multirow[t]{3}{*}{$20 \mathrm{i} 2989$} & \multirow[t]{3}{*}{ Arista } & White & 1.90 & 0.91 & 2.34 & 38.4 & 0.30 & 1.95 & 2.05 & 0.09 & - & 0.72 & - & - & 0.13 & 10.95 & - & 40.3 \\
\hline & & Blue & 2.64 & 0.76 & 2.10 & 40.5 & 0.34 & 2.55 & 2.53 & 0.12 & - & 1.92 & 0.53 & 0.23 & 0.29 & 8.51 & - & 37.0 \\
\hline & & Amber & 1.28 & 0.72 & 2.25 & 35.0 & - & 2.42 & 3.10 & 0.11 & - & 4.67 & - & - & - & 1.14 & - & 49.4 \\
\hline \multirow[t]{3}{*}{ 21AM3076 } & \multirow[t]{3}{*}{ Arista } & Blue & 1.77 & 0.65 & 1.66 & 39.6 & 0.20 & 3.09 & 2.19 & 0.12 & 0.09 & 1.32 & 0.27 & 0.14 & 0.42 & 8.80 & - & 39.7 \\
\hline & & Green & 1.03 & 0.91 & 2.62 & 37.6 & 0.33 & 1.85 & 3.62 & 0.19 & 0.03 & 0.79 & - & - & 3.29 & 1.27 & - & 46.5 \\
\hline & & Amber & 0.78 & 0.76 & 2.38 & 35.6 & 0.32 & 2.26 & 3.61 & 0.21 & 0.02 & 4.09 & - & - & 0.12 & 0.53 & - & 49.4 \\
\hline \multirow[t]{4}{*}{$27 i 3426$} & \multirow[t]{4}{*}{ Cuerda-seca } & White & 1.99 & 0.87 & 1.84 & 42.5 & 0.29 & 1.97 & 2.51 & 0.13 & - & 0.70 & - & - & 0.12 & 6.49 & - & 40.6 \\
\hline & & Blue & 2.29 & 0.62 & 1.57 & 41.6 & 0.32 & 2.27 & 2.17 & 0.11 & 0.02 & 1.72 & 0.50 & 0.21 & 0.42 & 6.82 & - & 39.3 \\
\hline & & Green & 1.04 & 0.74 & 1.66 & 34.7 & 0.39 & 1.55 & 2.61 & 0.11 & 0.19 & 0.78 & - & - & 2.71 & 1.92 & - & 51.6 \\
\hline & & Amber & 1.10 & 0.54 & 2.06 & 34.3 & 0.31 & 2.01 & 3.00 & 0.19 & - & 4.89 & - & - & 0.07 & 0.65 & - & 50.9 \\
\hline \multirow[t]{4}{*}{$30 F 7756$} & \multirow[t]{4}{*}{ Cuerda-seca } & White & 2.23 & 0.77 & 2.19 & 47.9 & 0.25 & 4.29 & 2.24 & 0.14 & 0.05 & 0.48 & - & - & 0.15 & 10.02 & - & 29.3 \\
\hline & & Blue & 2.94 & 0.50 & 2.13 & 47.5 & 0.16 & 2.50 & 2.07 & 0.13 & 0.04 & 1.34 & 0.20 & - & 0.34 & 9.94 & - & 30.2 \\
\hline & & Green & 1.63 & 0.95 & 3.40 & 42.8 & 0.27 & 2.64 & 3.13 & 0.21 & - & 1.37 & - & - & 3.16 & 1.76 & - & 38.7 \\
\hline & & Brown & 1.95 & 0.85 & 3.19 & 44.1 & 0.16 & 4.80 & 3.12 & 0.23 & 2.67 & 2.68 & - & - & 0.28 & 1.50 & - & 34.5 \\
\hline \multirow[t]{4}{*}{ 33Bi3839 } & \multirow{4}{*}{ Cuerda-seca } & White & 2.22 & 0.67 & 1.81 & 44.3 & 0.31 & 3.10 & 1.49 & 0.11 & 0.03 & 0.53 & - & - & 0.06 & 8.40 & - & 37.0 \\
\hline & & Blue & 2.47 & 0.72 & 1.88 & 42.6 & 0.31 & 3.46 & 2.59 & 0.20 & - & 0.87 & 0.29 & 0.12 & 0.29 & 9.28 & - & 34.9 \\
\hline & & Amber & - & 1.05 & 3.01 & 35.8 & 0.40 & 3.09 & 4.31 & 0.19 & - & 5.22 & - & - & 0.06 & - & - & 46.9 \\
\hline & & Brown & 1.65 & 0.84 & 3.10 & 40.4 & 0.31 & 3.46 & 3.91 & 0.20 & 2.94 & 1.68 & - & - & 0.09 & 1.54 & 0.19 & 39.7 \\
\hline \multirow[t]{4}{*}{ 3333BF4013 } & Cuerda-seca & White & 1.14 & 1.16 & 4.77 & 47.1 & 0.22 & 2.09 & 3.54 & 0.18 & 0.03 & 1.02 & - & - & 0.20 & 12.51 & - & 26.1 \\
\hline & & Blue & 1.73 & 0.60 & 2.87 & 40.0 & 0.15 & 2.22 & 2.20 & 0.15 & - & 1.68 & 0.39 & 0.21 & 0.41 & 18.74 & - & 28.6 \\
\hline & & Amber & 1.92 & 0.90 & 4.92 & 44.8 & 0.19 & 3.28 & 4.13 & 0.29 & 0.05 & 4.75 & - & - & - & 1.16 & - & 33.6 \\
\hline & & Brown & 1.43 & 1.21 & 5.36 & 46.5 & 0.19 & 2.78 & 4.47 & 0.24 & 2.60 & 2.44 & - & - & - & 1.12 & 0.32 & 31.3 \\
\hline 37af4167 & Arista & White & 2.73 & 0.94 & 2.64 & 50.2 & 0.19 & 1.93 & 2.87 & 0.11 & - & 0.59 & - & - & - & 9.00 & - & 28.8 \\
\hline & & Blue & 2.37 & 0.82 & 2.49 & 43.4 & 0.22 & 1.82 & 3.02 & 0.17 & - & 1.93 & 0.50 & 0.17 & 0.33 & 12.09 & - & 30.6 \\
\hline & & Green & 1.07 & 1.80 & 4.75 & 44.3 & 0.20 & 1.73 & 5.03 & 0.24 & 0.05 & 1.18 & - & - & 2.13 & 1.83 & - & 35.7 \\
\hline & & Brown & 0.83 & 1.04 & 3.19 & 41.3 & 0.20 & 1.53 & 3.52 & 0.15 & 1.47 & 1.51 & - & - & 1.36 & 0.93 & - & 43.0 \\
\hline 37af4179 & Arista & White & 1.78 & 1.82 & 2.76 & 43.0 & - & 3.70 & 2.60 & 0.13 & - & 0.76 & - & - & 0.11 & 11.21 & - & 32.2 \\
\hline & & Blue & 2.01 & 0.64 & 1.85 & 44.6 & 0.31 & 4.15 & 2.22 & 0.14 & - & 1.85 & 0.55 & 0.17 & 0.27 & 9.59 & - & 31.7 \\
\hline & & Green & 1.33 & 0.66 & 2.44 & 44.7 & 0.31 & 3.82 & 2.80 & 0.16 & - & 0.69 & - & - & 1.64 & 1.03 & - & 40.4 \\
\hline & & Brown & 1.52 & 0.68 & 2.47 & 42.3 & 0.32 & 4.13 & 2.86 & 0.17 & 3.28 & 1.38 & - & - & 0.15 & 0.78 & 0.18 & 39.8 \\
\hline $45 \mathrm{M} 4260$ & Cuerda-seca & White & 3.06 & 0.51 & 2.30 & 42.9 & 0.55 & 2.41 & 2.56 & 0.17 & - & 0.67 & - & - & - & 7.88 & - & 37.1 \\
\hline & & Blue & 3.39 & 0.39 & 1.83 & 41.9 & 1.00 & 2.12 & 1.67 & 0.12 & - & 1.71 & 0.44 & 0.23 & 0.27 & 8.15 & - & 36.8 \\
\hline & & Brown & 1.67 & 0.63 & 2.55 & 38.2 & 0.30 & 2.45 & 2.86 & 0.17 & 4.85 & 1.87 & - & - & 0.07 & 0.97 & 0.35 & 43.0 \\
\hline $86 \mathrm{i} 4886$ & Flat & Blue & 2.53 & 0.72 & 2.22 & 43.2 & 0.35 & 3.73 & 3.15 & 0.12 & 0.02 & 2.09 & 0.42 & 0.11 & 0.05 & 11.27 & 0.32 & 29.7 \\
\hline
\end{tabular}

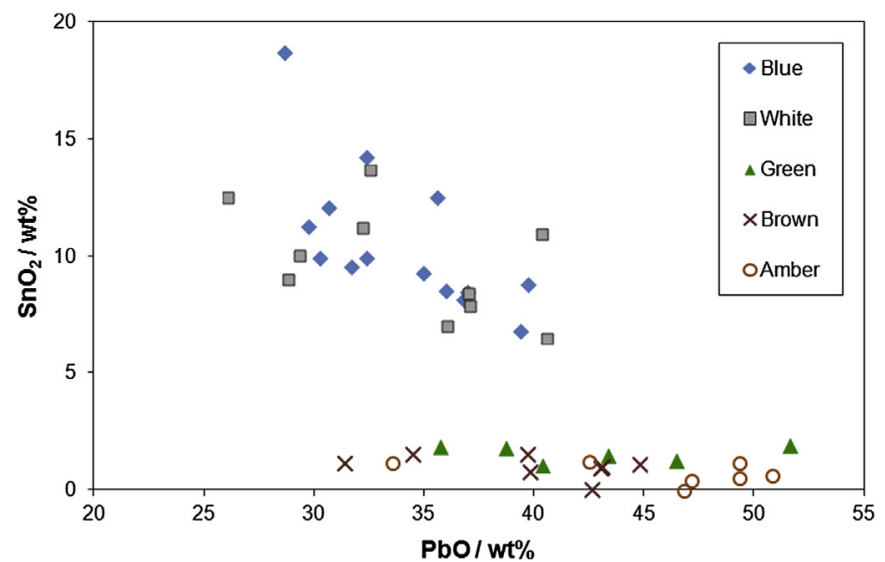

Fig. 2. $\mathrm{PbO}$ vs. $\mathrm{SnO}_{2}$ composition (wt\%) of different coloured glazes, obtained by $\mu$ PIXE. documented site of cobalt production, although those were of limited size (Roldán et al., 2006). Unfortunately there is lack of well-documented sources of cobalt production up to the 16th century (Soulier et al., 2002).

Green glazes show a content of ca. $2-3$ wt.\% of $\mathrm{CuO}$ and amber glazes display contents of ca. $4-5 \mathrm{wt} . \%$ of $\mathrm{Fe}_{2} \mathrm{O}_{3}$. To obtain the amber colour, iron was intentionally added, since the $\mathrm{Fe} / \mathrm{Pb}$ and $\mathrm{Fe} /$ Si ratios are clearly higher in amber glazes.

Finally, the black glazes show manganese associated with iron and barium, an association that has been already detected in Islamic cuerda-seca ceramics (11th century) (Pérez-Arantegui et al., 1999) and also in 17th century Portuguese majolica tiles (Coentro et al., 2012). The presence of barium could suggest the use of the mineral psilomelane $\left(\mathrm{BaMn}^{2+} \mathrm{Mn}^{4+}{ }_{8} \mathrm{O}_{16}(\mathrm{OH})_{4}\right)$ as a source of manganese, and typically the absence of it hinted at the use of pyrolusite $\left(\beta-\mathrm{MnO}_{2}\right)$. These two manganese minerals correspond to two important and worldwide distributed manganese sources (Coentro et al., 2012; Pérez-Arantegui et al., 1999). However, Tite et al. (2009) pointed out that this assumption represents an oversimplification, pointing to the wide range of $\mathrm{Mn}$ minerals in nature, together with veins of 
baryte $\left(\mathrm{BaSO}_{4}\right)$ and also Ba-feldspars. The $\mu$-Raman analyses did not provide us with information that could give clues about the manganese ores, identifying only compounds that most likely are formed during the firing process. One example is the wide identification of a manganese-bearing pyroxene, bustamite $\left(\mathrm{CaMnSi}_{2} \mathrm{O}_{6}\right)$ above the glaze-ceramic interface, with the most intense characteristic Raman bands at ca. 970 and $644 \mathrm{~cm}^{-1}$ (Fig. 3a). As already described by Pradell et al. (2013), taking into account the phase diagram of the $\mathrm{MnO}-\mathrm{SiO}_{2}$ binary, pyroxenes should start to appear at temperatures of about $950{ }^{\circ} \mathrm{C}$. Therefore bustamite recrystallizes from the melt. In addition, this compound was also found on the ceramic-glaze interface, probably arising from a reaction between the minerals from the ceramic paste that migrate to the glaze area. On sample 33Bi3839 two types of manganese oxides were identified, but due to unresolved bands it is impossible to ascertain the type of manganese oxides.

Finally on sample 45M4260 (cuerda-seca line), a manganese silicate $\left(\left(\mathrm{Mn}^{2+}, \mathrm{Mn}^{3+}\right)_{6} \mathrm{O}_{8} \mathrm{SiO}_{4}\right)$ named braunite was identified, with Raman bands at ca. 957, 692, 619, 511, 480, 336, 222 and $126 \mathrm{~cm}^{-1}$ (Fig. $3 \mathrm{~b}(\mathrm{i})$ ). Comparing the spectra obtained for braunite with the reference spectrum from the RRUFF database, our spectra are shifted to a lower wavenumber ca. $6 \mathrm{~cm}^{-1}$ for every Raman band (Fig. 3b(ii)). This could be due to cation substitution in the structure of braunite, where $\mathrm{Mn}^{3+}$ can be substituted by $\mathrm{Fe}^{3+}$, and $\mathrm{Mn}^{2+}$ by $\mathrm{Mg}^{2+}$ and $\mathrm{Ca}^{2+}$ (Bhattacharyya et al., 1984). Braunite was already identified on 17th c. Portuguese tiles (Coentro et al., 2012) and recently by Pradell et al. (2013) on late Renaissance polychrome majolica (17th c.), and 11th c. Almohade tin-glazed ceramic from Mallorca, and by Molera et al. (2013) on Islamic glazes (10-11th c.) from Murcia, on HispanoMoresque glazes from Valencia (13-14th c.), and on a 17th c. glaze from Catalonia. The latter study explains that the coexistence of braunite and bustamite on the black glazes indicates firing temperatures above $950{ }^{\circ} \mathrm{C}$ Molera et al. (2013). Fig. 4 illustrates the coexistence of several Mn-rich crystals, most likely braunite, and a Ca-pyroxene, wollastonite (see Chapter 3.3) in the glaze-ceramic interface.

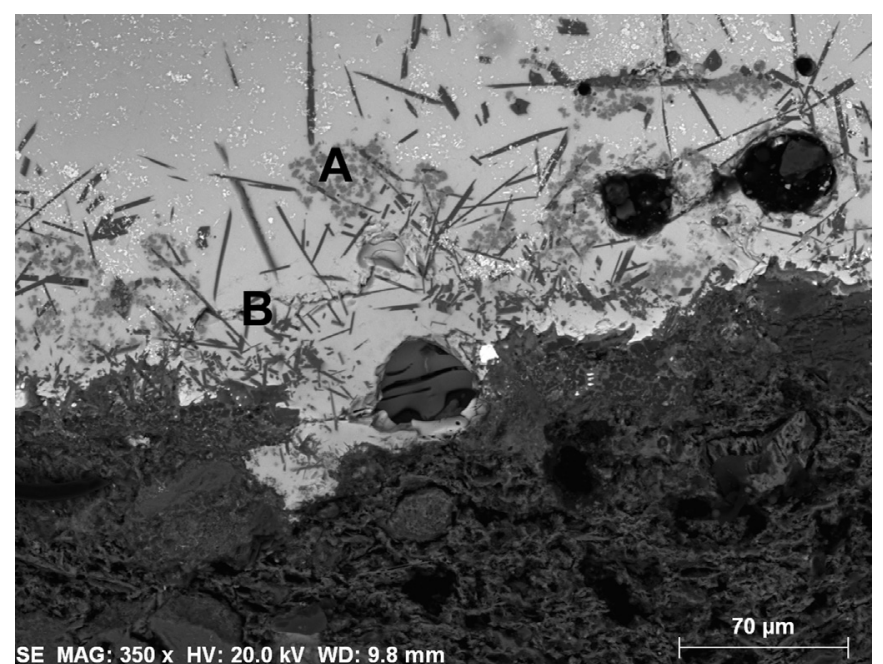

Fig. 4. SEM image of a cross-section from the cuerda-seca (sample 47M4260) where a thick glaze-ceramic interface can be seen, thick glaze-ceramic interface can be seen, as well as the coexistence of several Mn-rich crystals (A), most likely braunite, and a Ca-pyroxenoid, wollastonite (B).

\subsection{Morphological and mineralogical characterisation of glazes and the glaze-ceramic interface}

The characteristics of the glaze and the glaze-ceramic interface can be a valuable source of information for the differentiation of production technologies (Molera et al., 1997b, 2001a; Vendrell-Saz et al., 2006). The tiles from Santa Clara Monastery display very homogeneous glazes, with scarce crystalline inclusions, more abundant at the glaze-ceramic interface, with the exception of small and well-distributed cassiterite agglomerates. Many mineral inclusions and gas bubbles were found located in or near the glazeceramic interface. Tin oxide crystals are homogeneously dispersed throughout the glaze (Fig. 5a), forming small agglomerates with dimensions ranging from less than $1 \mu \mathrm{m}$ up to $10-20 \mu \mathrm{m}$. Size and
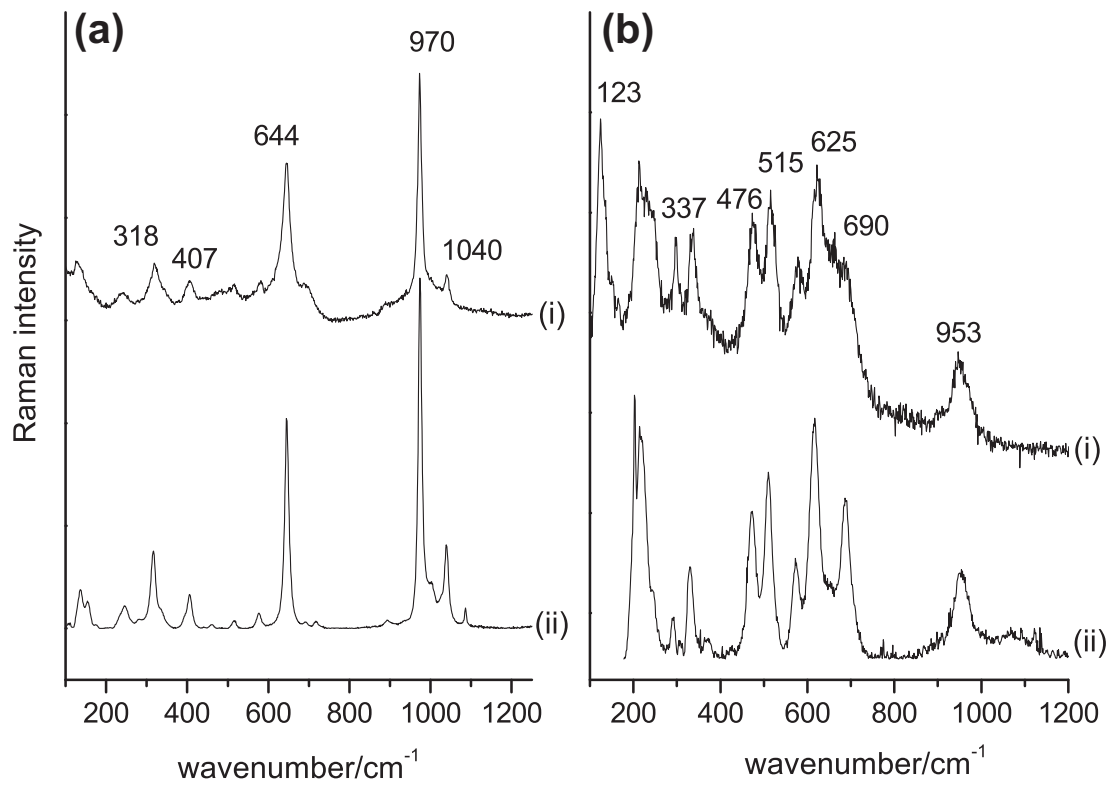

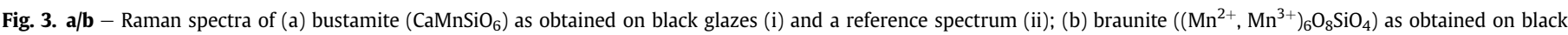
glazes (i) and a reference spectrum (ii). 

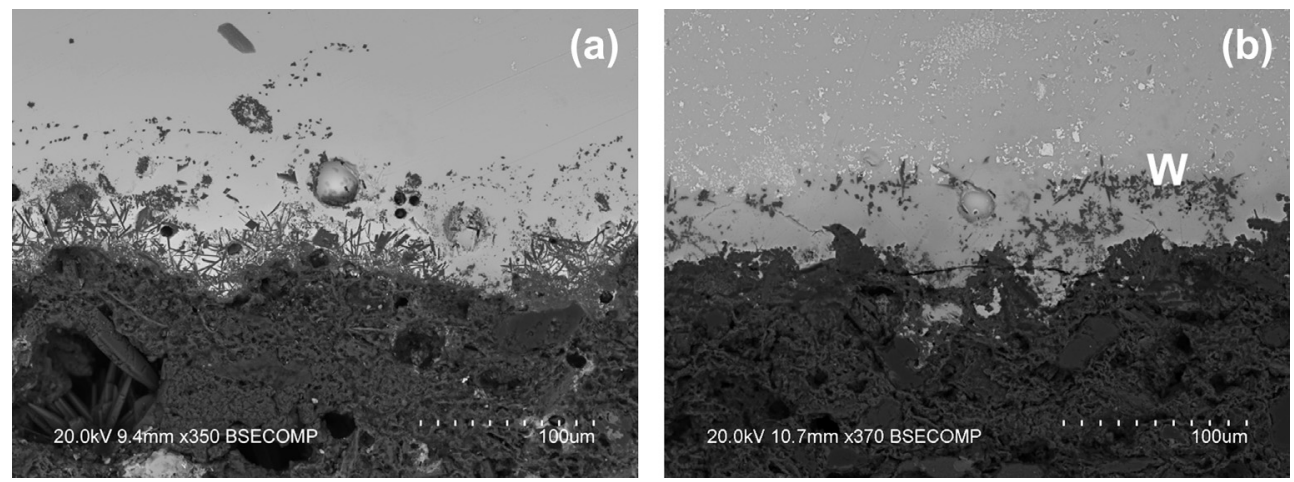

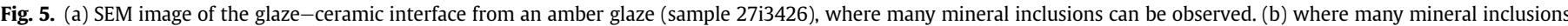

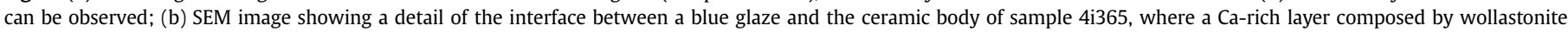
crystals (W) can be observed.

distribution of these crystals are very important characteristics of the production technology (Molera et al., 1997a; Vendrell-Saz et al., 2006). The $\mathrm{SnO}_{2}$ contents in white and blue glazes, their small size and homogeneous distribution show more resemblance with Islamic tin-glazed pottery, instead of Hispano-Moresque pottery. Measurements of the glaze thickness revealed a wide range of values although the majority of the measured glazes are set within ca. $200 \mu \mathrm{m}-500 \mu \mathrm{m}$, showing considerable variations within the same sample and even within the same glaze area. The thickness of the glaze-ceramic interface was measured between $30 \mu \mathrm{m}$ and $100 \mu \mathrm{m}$. According to Molera et al. (2001a), this is consistent with a single fire process. Green, amber and black coloured glazes show a larger number of crystals in this interface, which become more dispersed the further the distance from the ceramic body (Fig. 5a), and also hold thicker interfaces. For white and blue colours, the interface sometimes shows an intermediate area, very homogeneous and without cassiterite crystals, delimited by the ceramic body and a line of Ca-rich crystals, as Fig. 5b illustrates.

The chemical composition of the glaze-ceramic interface was first characterized by SEM-EDS and then point analysis by $\mu$-Raman microscopy, trying to match the areas analysed by both techniques. This strategy allows a thorough visual chemical mapping as our first information starting point, followed by precise identification of the compounds formed during the digestion/diffusion process in the ceramic-glaze interface. Raman microscopy was also invaluable to identify some mineral phases in the ceramic bodies, providing important information on the tile technology, namely firing conditions, post-burial processes and understanding the reactions at the glaze-ceramic interface. The most common occurrences in the ceramic bodies were wollastonite $\left(\mathrm{CaSiO}_{3}\right)$, quartz $\left(\alpha-\mathrm{SiO}_{2}\right)$, Kfeldspars ( $\left.\mathrm{KAlSi}_{3} \mathrm{O}_{8}\right)$, oligoclase $\left((\mathrm{Ca}, \mathrm{Na})(\mathrm{AlSi})_{4} \mathrm{O}_{8}\right)$, hematite $(\alpha-$ $\left.\mathrm{Fe}_{2} \mathrm{O}_{3}\right)$, ankerite $\left(\mathrm{Ca}(\mathrm{Fe}, \mathrm{Mg}, \mathrm{Mn})\left(\mathrm{CO}_{3}\right)_{2}\right)$, aragonite $\left(\mathrm{CaCO}_{3}\right)$ and analcime $\left(\mathrm{NaAlSi}_{2} \mathrm{O}_{6} \cdot \mathrm{H}_{2} \mathrm{O}\right)$. From the minerals identified, we highlight the ones that can give us some insight on the firing conditions, namely wollastonite, K-feldspars, plagioclases and the zeolite analcime. Wollastonite, a Ca-pyroxenoid (characteristic Raman bands at 970, 636 and $411 \mathrm{~cm}^{-1}$, Fig. 6a) is a widespread mineral phase in the ceramic body, an outcome of the thermal decomposition of calcite from the raw materials. Feldspars such as orthoclase/sanidine and oligoclase are originated at somewhat higher temperatures (close to $1000{ }^{\circ} \mathrm{C}$ ) (Pradell et al., 2010). Analcime, a Na-bearing zeolite, is a common weathering compound of highly vitrified ceramic materials (ca. $1000{ }^{\circ} \mathrm{C}$ ) in a wet environment (Schwedt et al., 2006). The tiles were submersed for many centuries so it is not surprising to find weathering compounds from the burial conditions. Interestingly, its presence in the ceramic bodies is an indicator of a high temperature ceramic (Pradell et al., 2010).
When moving to the glaze-ceramic interface, SEM-EDS analysis indicates a Ca-rich interface and characterized by wollastonite crystals, already identified on the ceramic bodies. Very rarely, some crystals of $\alpha$-quartz are identified. Wollastonite is preferentially formed due to an excess of Si from the digestion/process glazeceramic and, simultaneously a deficiency in Al. Also, its favoured formation seems to be related to the existence of large $\mathrm{CaO}$ and quartz grains, otherwise it would be an intermediate phase, leading to the formation of anorthite $\left(\mathrm{CaAl}_{2} \mathrm{Si}_{2} \mathrm{O}_{8}\right)$ (Traoré et al., 2000). The $\mathrm{K}$-rich areas are comprised by potassium feldspars (general formula $\mathrm{KAlSi}_{3} \mathrm{O}_{8}$ ), although it was not possible to identify the precise geometry of the feldspar crystals. There is no indication of lead-potassium feldspars, typical of the interaction with a lead-rich glaze (Pradell et al., 2010).

On the glaze-ceramic interface of samples 21AM3076 and $33 \mathrm{bi3839}$ (green glaze), tin was also identified by $\mu$-Raman in the form of malayaite $\left(\mathrm{CaSnOSiO}_{4}\right)$ (Fig. 6b), a calcium-tin silicate belonging to the titanite group, with characteristic Raman bands at 571,365 , and $322 \mathrm{~cm}^{-1}$. Malayaite can be synthesized from equimolar parts of $\mathrm{CaO}, \mathrm{SiO}_{2}$ and $\mathrm{SnO}_{2}$ through a thermal process, but it can also be formed from a reaction between $\mathrm{SnO}_{2}$ and wollastonite $\left(\mathrm{CaSiO}_{3}\right)$ (Mulholland, 1984; Piña et al., 2005). In addition, studies on the synthesis of malayaite pigments suggest that the existence of a transition metal ion (such as copper) should favour the formation of this calcium-tin silicate (Mulholland, 1984).

In sample 33Bi3839, andradite crystals $\left(\mathrm{Ca}_{3} \mathrm{Fe}_{2} \mathrm{Si}_{3} \mathrm{O}_{12}\right.$, a neosilicate from the garnet group) were identified by $\mu$-Raman in the amber glaze, with characteristic bands at 882,514 and $361 \mathrm{~cm}^{-1}$ (Fig. 6c), sometimes in admixture with wollastonite crystals. The shifts in the Raman bands are consistent with an andradite structure where $\mathrm{Fe}^{3+}$ is partially substituted by ions such as $\mathrm{Ti}^{4+}$ or $\mathrm{Mg}^{2+}$. Both SEM-EDS point analysis and $\mu$-PIXE show Mg contents near $1 \mathrm{wt} . \%$ in the amber glazes. This neosilicate could arise from the reaction between wollastonite and iron oxides in excess such as magnetite or hematite in an oxidizing atmosphere (Zhang and Saxena, 1991). Alongside andradite, $\mu$-Raman also identified a magnesioferrite $\left(\mathrm{MgFe}_{2} \mathrm{O}_{4}\right)$ with a strong Raman band at ca. $619 \mathrm{~cm}^{-1}$ (Fig. 6d), slightly shifted from recorded established values. Again the $\mathrm{Mg}$ contents could lead to the formation of magnesium and iron spinels, such as magnesioferrite.

Finally on sample 33Bi3839, an inverse spinel $\mathrm{NiFe}_{2} \mathrm{O}_{4}$ was identified (Hosterman, 2011) on the blue glaze with Raman characteristic bands at ca. 707, 495, 336 and $70 \mathrm{~cm}^{-1}$ (Fig. 6e). Since it is a very rare specimen in nature, it is more likely to have been formed in the glaze-ceramic interface (RRUFF:Trevorite). Blue glazes contain a significant $\mathrm{Ni}$ content (up to ca. $5 \mathrm{wt} \%$ ). 


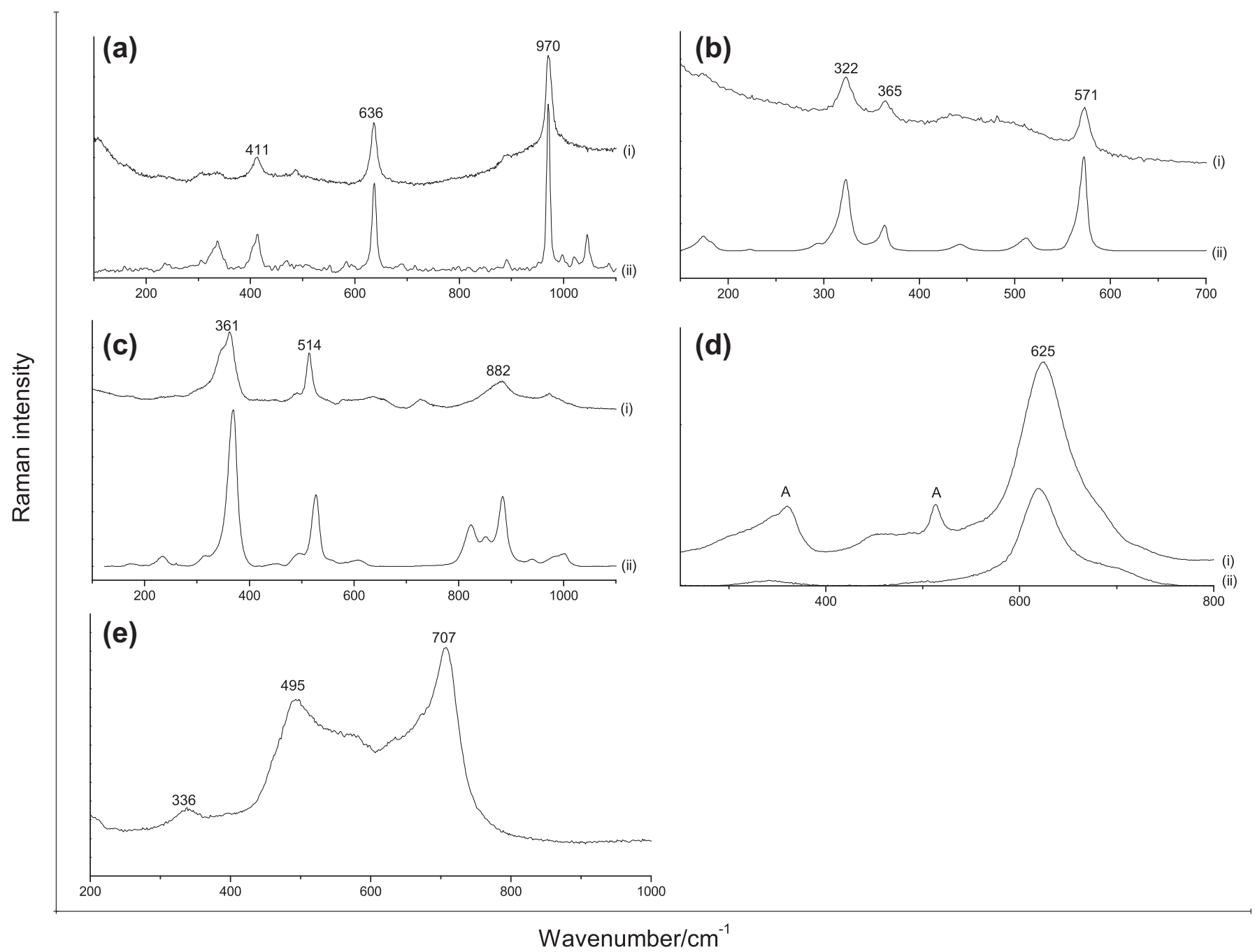

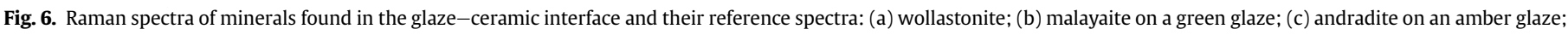
(d) magnesioferrite on an amber glaze; (e) a nickel ferrite on a blue glaze (no reference spectra).

\section{Conclusions}

For the first time Hispano-Moresque tiles located in the Portuguese territory (Coimbra, central Portugal) and found on an archaeological context were chemically and morphologically analysed. The importance of this study is closely linked to a wider project on the provenance of Hispano-Moresque tiles in Portugal, a subject clouded in controversy amongst art history experts.

The chemical characterisation of the Hispano-Moresque tiles from Santa Clara-a-Velha revealed a lead glaze technology that has similarities both with Islamic and Hispano-Moresque glazed ceramics. On one hand, glaze homogeneity, high tin contents (ca. 7$14 \mathrm{wt} . \%)$ and very small and well dispersed tin oxide crystals suggests closeness to the Islamic technology. On the other hand, very thick interfaces, with several mineral inclusions most likely created during firing from the strong reaction between the glaze and an unfired ceramic body, suggesting a single-firing process, shows more similarity with Hispano-Moresque glazed ceramics. This study is the first analytical indicator of a production technology with important differences from the Hispano-Moresque workshops (such as Seville, Toledo, etc.) and points out to a possible local production.

Regarding the chemical composition of the glaze-ceramic interface, mostly wollastonite $\left(\mathrm{CaSiO}_{3}\right)$ and also K-feldspars (of general formula $\mathrm{KAl}_{3} \mathrm{SiO}_{8}$ ), implies not only a calcareous nature of the ceramic paste, but also firing temperatures between $950{ }^{\circ} \mathrm{C}$ and $1000{ }^{\circ} \mathrm{C}$. On manganese-coloured glazes bustamite $\left(\mathrm{CaMnSi}_{2} \mathrm{O}_{6}\right)$, and braunite $\left(\left(\mathrm{Mn}^{2+}, \mathrm{Mn}^{3+}\right)_{6} \mathrm{O}_{8} \mathrm{SiO}_{4}\right)$ were identified. The coexistence of both minerals indicates temperatures higher than $950{ }^{\circ} \mathrm{C}$. Besides cassiterite $\left(\mathrm{SnO}_{2}\right)$, identified in all colours, other compounds were identified on the glaze-ceramic interface, malayaite $\left.(\mathrm{CaSnOSiO})_{4}\right)$, andradite $\left(\mathrm{Ca}_{3} \mathrm{Fe}_{2} \mathrm{Si}_{3} \mathrm{O}_{12}\right)$, magnesioferrite $\left(\mathrm{MgFe}_{2} \mathrm{O}_{4}\right)$ and a nickel ferrite $\left(\mathrm{NiFe}_{2} \mathrm{O}_{4}\right)$.

Although the collection studied presents more decorations techniques other than cuerda-seca and arista, those comprise the majority of the collection, and therefore their results were compared. In addition, these two techniques of decorations were also the prevailing ones during the time period of their attribution (15th-16th c.). The chemical characterisation does not hint at different recipes or different firing processes for cuerda seca and arista tiles. Thus, it is likely that the production technology is very similar, if not the same, for both techniques. Our data implies a single-firing process, and this procedure would allow a faster and more economic production. However, archaeological evidence includes unglazed arista tiles among the collection that was found in the Monastery of Santa Clara-a-Velha. One plausible hypothesis could stem from a more recent production of tiles destined to the Monastery of Santa Clara-a-Nova built in the 17th century (the new house of the Clarissa nuns). 
In conclusion, we should mention that there are no studies on architectural tiles from this period, so it is possible that their production technology developed in a different way than for other glazed ceramic objects.

\section{Acknowledgements}

The authors thank the Monastery of Santa Clara-a-Velha, in particular Dr. Artur Côrte-Real, for providing the samples for this study. We also thank Dra. Catarina Leal for the support given when selecting the referred samples.

Authors S. Coentro and V. S. F. Muralha acknowledge the support of Fundação para a Ciência e Tecnologia (grants SFRH/BD/73007/ 2010 and SFRH/BPD/42286/2007, respectively).

\section{References}

Bhattacharyya, P.K., Dasgupta, S., Fukuoka, M., Roy, S., 1984. Geochemistry of braunite and associated phases in metamorphosed non-calcareous manganese ores of India. Contrib. Mineralogy Petrol. 87, 65-71.

Chapoulie, R., Delery, C., Daniel, F., Vendrell-Saz, M., 2005. Cuerda seca ceramics from Al-Andalus, Islamic Spain and Portugal (10th-12th centuries AD): investigation with SEM-EDX and cathodoluminescence. Archaeometry 47 (3), 519-534.

Coentro, S., Mimoso, J.M., Lima, A.M., Silva, A.S., Pais, A.N., Muralha, V.S.F., 2012. Multi-analytical identification of pigments and pigment mixtures used in 17th century Portuguese azulejos. J. Eur. Ceram. Soc. 32 (1), 37-48.

Côrte-Real, A., Leal, C., Munhós, M., Macedo, F.P., Bernardo, L., Ferreira, M.A., Santos, P.C., 2010. O Mosteiro de Santa Clara-a-Velha de Coimbra: investigação, musealização e síntese de aspectos orientalizantes no espólio. In: Actas do IV Congresso de Arqueologia Penínsular: As idades medieval e moderna na Península Ibérica, Faro, pp. 113-128.

Hosterman, B.D., 2011. Raman Spectroscopic Study of Solid Solutions of Spinel Oxides. UNLV theses/dissertations/professional papers/Capstones. Paper 1087. University of Nevada, Las Vegas, pp. 87-90.

Martínez Caviró, B., 1996. Ceramica Hispanomusulmana, Andalusi y Mudejar. Ediciones El Viso, Madrid.

Molera, J., Pradell, T., Merino, L., García-Vallés, M., García-Orellana, J., Salvadó, N., Vendrell-Saz, M., 1997a. La tecnología de la cerámica Islámica y Mudéjar. Caesaraugusta $73,15-41$.

Molera, J., Vendrell-Saz, M., García-Vallés, M., Pradell, T., 1997b. Technology and colour development of Hispano-Moresque lead-glazed pottery. Archaeometry 39 (1), 23-39.

Molera, J., Pradell, T., Vendrell-Saz, M., 1998. The colours of Ca-rich ceramic pastes: origin and characterization. Appl. Clay Sci. 13, 187-202.

Molera, J., Pradell, T., Salvadó, N., Vendrell-Saz, M., 2001a. Interactions between clay bodies and lead glazes. J. Am. Ceram. Soc. 84 (5), 1120-1128.

Molera, J., Vendrell-Saz, M., Pérez-Arantegui, J., 2001b. Chemical and textural characterization of tin glazes in Islamic ceramics from Eastern Spain. J. Archaeol. Sci. 28, 331-340.

Molera, J., Pradell, T., Salvadó, N., Vendrell-Saz, M., 2009. Lead frits in Islamic and Hispano-Moresque glazed productions. In: Shortland, A., Freestone, I.C., Rehren, T. (Eds.), From Mine to Microscope: Advances in the Study of Ancient Technology. Oxbow Books, Oxford, pp. 1-10 (Chapter 1).
Molera, J., Coll, J., Labrador, A., Pradell, T., 2013. Manganese brown decorations in 10th to 18th centuries Spanish tin glazed ceramics". Appl. Clay Sci.. http:// dx.doi.org/10.1016/j.clay.2013.05.018.

Mulholland, I.R., 1984. Malayaite and tin-bearing garnet from a skarn at Gumble, NSW, Australia. Mineral. Mag. 48, 27-30.

Pérez-Arantegui, J., Soto, M., Ramón Castillo, J., 1999. Examination of the "cuerda seca' decoration technique on Islamic ceramics from al-Andalus (Spain). J. Archaeol. Sci. 26, 935-941.

Pérez-Arantegui, J., Ortega, J.M., Escriche, C., 2005. La tecnología de la cerámica Mudéjar entre los siglos XIV y XVI: las producciones esmaltadas de las zonas de Teruel y Zaragoza. In: VI Congreso Ibérico de Arqueometría: Avances en Arqueometría, pp. 89-96.

Piña, C., Arriola, H., Nava, N., 2005. Study of malayaite and malayaite cobalt pigment. Hyperfine Interact. 161, 93-97.

Pradell, T., Molera, J., Salvadó, N., Labrador, A., 2010. Synchrotron radiation microXRD in the study of glaze technology. Appl. Phys. A 99, 407-417.

Pradell, T., Molina, G., Molera, J., Pla, J., Labrador, A., 2013. The use of micro-XRD for the study of glaze color decorations. Appl. Phys. A 111, 121-127.

Roldán, C., Coll, J., Ferrero, J., 2006. EDXRF analysis of blue pigments used in Valencian ceramics from the 14th century to modern times. J. Cult. Herit. 7, 134-138.

Schwedt, A., Mommsen, H., Zacharias, N., Buxeda I Garrigós, J., 2006. Analcime crystallization and compositional profiles - comparing approaches to detect post-depositional alterations in archaeological pottery. Archaeometry 48, 237-251.

Soulier, I., Blet, M., Gratutze, B., 2002. Verres et céramiques glaçurées archéologiques: complémentarité entre les textes et les resultats d'analyses. In: Materials: Research, Development and Applications, Proceedings of the XXth Internaional Congress of History of Science (Liège, 20-26 July 1997). De Diversis Artibus, vol. XV. Brepols Ed., pp. 210-228.

Tite, M.S., Shortland, A., Maniatis, Y., Kavoussanaki, D., Harris, S.A., 2006. The composition of the soda-rich and mixed alkali plant ashes used in the production of glass. J. Archaeol. Sci. 33, 1284-1292.

Tite, M.S., Maniatis, Y., Kavoussanaki, D., Panagiotaki, M., Shortland, A.J., Kirk, S.F., 2009. Colour in Minoan faience. J. Archaeol. Sci. 36, 370-378.

Traoré, K., Kabré, T.S., Blanchart, P., 2000. Low temperature sintering of a pottery clay from Burkina Faso. Appl. Clay Sci. 17, 279-292.

Trindade, R.A.A., 2007. Revestimentos Cerâmicos Portugueses. Meados do século XIV à primeira metade do século XVI. Edições Colibri/Faculdade de Ciências Sociais e Humanas da Universidade Nova de Lisboa, Lisboa.

Vendrell-Saz, M., Molera, J., Roqué, J., Pérez-Arantegui, J., 2006. Islamic and Hispano-Moresque (múdejar) lead glazes in Spain: a technical approach. In: Maggetti, M., Messiga, B. (Eds.), Geomaterials in Cultural Heritage. The Geological Society of London, London, pp. 163-173.

Zhang, Z., Saxena, S.K., 1991. Thermodynamic properties of andradite and application to skarn with coexisting andradite and hedenbergite. Contrib. Mineral. Petrol. 107, 255-263.

Zucchiatti, A., Bouquillon, A., Katona, I., D’Alessandro, A., 2006. The 'Della Robbia blue': a case study for the use of cobalt pigments in ceramics during the Italian Renaissance. Archaeometry 48 (1), 131-152.

\section{Web references:}

RRUFF Project Database. http://rruff.info/(accessed 10.01.13.).

Trevorite (online). RRUFF Project Database. http://rruff.info/doclib/hom/trevorite. pdf (accessed 10.01.13.) 